\title{
Profesyonel Turist Rehberlerinin Kaçak Rehberlik Faaliyetlerini Algılamalarma Yönelik Bir Araştırma
}

\begin{abstract}
Büşra ŞAHİ* Sena KAYA** Sevilay CESUR ${ }^{* * *}$ Emrah ÖZKUL $^{* * * *}$ Selda UCA $^{* * * * *}$
ÖZET

Günümüzde turist rehberliği, turizm endüstrisinin vazgeçilmez dinamiklerinden biri haline gelmiştir. Özellikle turizm faaliyetlerinin artış gösterdiği son yıllarda Türkiye’ye gelen ziyaretçi sayılarındaki artışın sürdürülebilirliğinin sağlanmasında turist rehberlerinin önemli rolleri bulunmaktadır. Yapılan çalışmada, "Turist Rehberliği Birliği” bünyesinde görev yapmakta olan profesyonel turist rehberlerinin kaçak rehberlik faaliyetlerine karşı düşüncelerinin ve algılamalarının ne yönde olduğu tespit edilerek çözüm önerileri geliştirilmesi amaçlanmıştır. Bu amaç doğrultusunda yarı yapılandırılmış görüşme tekniği yirmi üç turist rehberinden e-posta yolu ile veriler elde edilmiştir. Çalışma sonucunda, profesyonel turist rehberlerinin, mesleki açıdan (işsizlik, mesleki itibar) ve destinasyon açısından (yanlış tanıtım) olumsuz etkilendikleri tespit edilmiştir. Kaçak rehberlik faaliyetlerinin son bulmamasının sebebi olarak denetimlerin azlığı katılımcılar tarafından vurgulanmıştır. Çalışma sonunda ayrıca kaçak rehberlik faaliyetlerinin önüne geçilmesi adına çözüm önerilerine yer verilmiştir.
\end{abstract}

Araştırma Makalesi

Geliş: 08.11.2020

Kabul: 02.01.2021

Anahtar Kelimeler:

Kaçak Rehberlik,

Profesyonel Turist

Rehberi,

Turizm,

\section{A Survey of Professional Tourist Guides to Perceive Illegal Guidance Activities}

\section{ABSTRACT}

Today, tourist guiding has become one of the indispensable dynamics of the tourism industry. Tourist guides have an important role in ensuring the sustainability of the increase in the number of visitors to our country, especially in recent years, when tourism activities have increased. In this study, it was aimed to develop solutions by determining the thoughts and perceptions of professional tourist guides working within the "Tourist Guiding Association" against illegal guidance activities. For this purpose, by using semi-structured interview technique, the data were obtained from twenty-three professional tourist guides via e-mail. As a result of the study, it was determined that professional tourist guides were negatively affected in terms of professional (unemployment, professional reputation) and destination (misrepresentation). The lack of inspections was emphasized by the participants as the reason why illegal guidance activities did not end. At the end of the study, solution suggestions were also included to prevent illegal guidance activities.
Research Article

Received: 08.11.2020

Accepted: 02.01.2021

Keywords:

Illegal Guidance,

Professional Tourist

Guide,

Tourism.

* Yüksek Lisans Öğrencisi, Kocaeli Üniversitesi, sahinbusra06@ gmail.com, ORCID ID: https://orcid.org/00000003-2486-7154

** Yüksek Lisans Öğrencisi, Kocaeli Üniversitesi, senakayaa67@gmail.com, ORCID ID: https://orcid.org/00000002-8995-7938

**** Yüksek Lisans Öğrencisi, Kocaeli Üniversitesi, sevilaycesur14@gmail.com, ORCID ID: https://orcid.org/0000-0003-1722-4601

**** Doç. Dr., Kocaeli Üniversitesi, Turizm İşletmeciliği Anabilim Dalı, emrahozkul@gmail.com, ORCID ID: https://orcid.org/0000-0002-7938-6916

****** Doç. Dr., Kocaeli Üniversitesi, Gastronomi ve Mutfak Sanatları Anabilim Dalı, seldauca@ gmail.com, ORCID ID: https://orcid.org/0000-0002-9308-9184 


\section{GíRíş}

Turizm endüstrisi temel olarak konaklama, ulaşım, yardımcı hizmetler ve satış olmak üzere dört ana bileşenden oluşan bir yapıya sahiptir (Camilleri, 2017: 6). Turizm işletmelerinin faaliyetlerini sürdürmesindeki temel amaç yerli ve yabancı turistler başta olmak üzere yerel halkın ihtiyaçlarının karşılanmasına yardımcı olmaktır. (Timur ve Bardakoğlu, 2015: 32). Turizm endüstrisinin belki de insanla, çevresel, toplumsal ve kültürel ihtiyaçlarla en ilişkili ayağını rehberler temsil etmektedirler. Rehberlerin turistlerle olan ilişkileri ve etkileşimleri turistlerin yerel halk ile olan ilişkilerini ve turist memnuniyetini de doğrudan etkilemektedir (Avcikurt, 2009: 76).

Turist rehberi, genel olarak kültürel/tarihi alanlarda mesleğini yerine getirmesi ile birlikte sahip olduğu özel dilbilgisi sayesinde ilham veren bir yapıda bulunarak eğlenceli bir şekilde çevresini yorumlama özelliğine sahip olan kişi olarak tanımlanabilmektedir (Ap ve Wong, 2001: 551).

Ülke tanıtımı açısından stratejik önem taşıyan rehberlik mesleğinin birçok kronik, yasal, endüstriyel ve kişisel sorunları olduğu söylenebilmektedir. $\mathrm{Bu}$ mesleki sorunların tespit edilip çözüme kavuşturulması gerektiği ve böylece turizm işletmelerinden turistlere kadar uzanan süreçte turist rehberlerinden daha etkin ve verimli yararlanılabileceğini söylemek mümkündür (Genç, 2018: 1).

Rehberler ülkelerin kültür elçileri olarak algılanmaktadır. Rehberlerin daha verimli ve aktif bir şekilde mesleklerini yerine getirebilmelerine engel olan nedenler arasında kaçak rehberlik, düşük ücret, çalışma saatleri, sosyal güvenlik ve eğitim yetersizliği gibi pek çok sorun yer almaktadır. Rehberleri birçok yönden etkileyen ve bir sorun olarak belirlenen kaçak rehberlik faaliyetlerinin önlenmesine yönelik olarak çözümler geliştirilerek bunların uygulanması gerekmektedir. Buradan hareketle bu çalışma, “Turist Rehberliği Birliği” bünyesinde görev yapmakta olan profesyonel turist rehberlerinin kaçak rehberlik faaliyetlerine karşı düşüncelerinin ve algılamalarının ne yönde olduğunun tespit edilmesi amaçlanmaktadır.

\section{TURIST REHBERLİĞİ KAVRAMI}

Dünya Turist Rehberleri Federasyonu (WFTGA) turist rehberliğini "Ziyaretçilere kendi tercihleri doğrultusundaki dillerde kılavuzluk eden ve ziyaret edilen bölgeye özgü kültürel ve doğal miras1 aktaran kişi” olarak tanımlamaktadır (WFTGA, 2003).

Türkiye'de 7 Haziran 2012 tarihinde kabul edilmiş olan 6326 sayılı Turist Rehberliği Meslek Kanunu'na göre turist rehberliği hizmeti "Seyahat acentelerinin faaliyet kapsamı dişında yerli veya yabancı turistlerin tur planlaması esnasında seçtikleri dilin kullanılarak ülkenin kültür, turizm, tarih, çevre, doğa, sosyal veya benzer değer ve varlıklarının kültür ve turizm politikaları çerçevesinde 
tanıtılıp gezdirilmesi; acenteler tarafından programlanmış olan turların tüketicinin satın aldığı şekilde sürdürülüp acentenin temsilinin sağlanmasıdır” şeklinde ifade edilmektedir (TUREB, 2013).

Literatürde ise turist rehberi ile ilgili farklı tanımlamalar yapılmıştır. Turist rehberleri, yalnızca birkaç cümle ile çeviri yapan kişiler değil aynı zamanda turistlerin başka kültürlerle tecrübe kazanmasını, turistin başka kültürleri, görmeyi, duymayı ve hissetmesini sağlayan kişilerdir (Dahles, 2002: 786). Turist rehberleri turistlere sundukları hizmetler ile ziyaret edilen destinasyon hakkında genel izlenim ve memnuiyeti oluşturmaktadırlar. Bundan dolayı da hizmetin sunulmasında başlıca öneme sahiptirler (Ap ve Wong, 2001: 551). Turist rehberinin birçok rolü bulunmaktadır. Cohen (1985) çalışmasında turist rehberinin lider, ara bulucu ve yol gösterici rolleri üzerinde durmuştur.

\section{Turist Rehberliği Mesleğinin Tarihsel Gelişimi}

İlk insanlar göçebe olarak devam ettirdikleri hayattan yerleşik düzene geçmeleri ve neolitik çağ ile birlikte bir bakıma endüstriyel sayılabilecek üretime başlamaları ile bütün gereksinimlerini yalnız başlarına karşılayamayacak hale gelmişlerdir. Bu durumda ilk olarak komşularıyla, ardından şehirlerde yaşayan yöneticilerle alışverişe başlamışlardır. $\mathrm{Bu}$ alışverişler ile birlikte ilk seyahatler, şehir dışı ulaşımlar ve tam bir kanıt olmaması ile beraber ilk turizm faaliyetleri başlamıştır (Ahipaşaoğlu, 2006: 4-5).

Turizm faaliyetlerinin başlamasıyla beraber çeşitli turizm meslek kolları da doğmuştur. Bu meslek kollarından biri de turizm hizmetinin sunulmasında çok önemli rol oynayan turist rehberliği mesleğidir (Çokal, 2019: 43). Dünya tarihinde yazılı kaynaklara geçmiş ilk turist rehberleri Mısırlı rahipler olarak bilinmektedir. Ancak, M.Ö. 776 ‘da olimpiyat oyunlarının başlaması ile organize seyahatler başlamış ve ardından turist rehberliği mesleği ortaya çıkmıştır. Her yıl Mısırlı, Mezopotamyalı, Finikeli insanlar oyunları izlemek üzere Yunanistan'a gitmişlerdir. Yunanlılar da, o gezilerden kaynaklanan talebe cevap verebilmek amacıyla, konaklama ve eğlence yerleri inşa etmişlerdir. Bununla birlikte, ziyaretçileri karşılayıp konaklama yerlerine ya da etkinliklere yönlendiren özel görevliler ortaya çıkmıştır. Bu görevlerle "proxenos" denen kişiler, yani "ilk tur rehberleri” olarak da bilinen kişiler tarih sahnesinde yer almaya başlamıştır (Toker, 2011: 25).

Anadolu'da doğup yetişen ünlü tarihçi ve coğrafyacı Herodot, gezip gördüğü yerleri ve oraların geleneklerini aktaran ilk rehberlerden olmuştur. Bununla birlikte kültür turizmini başlatan kişi olarak da sayılabilmektedir. Sanayi Devrimi'ni takip eden yıllar ile birlikte de turizm ve turist rehberliği günümüzdeki şekline ulaşmıştır. 1930’lu yıllardan itibaren ise bölgesel olarak rehberlerin eğitimi ve örgütlenme çalışmaları başlamış olup turizmin gelişmesi ve kitle turizminin başlaması ile profesyonel turist rehberliği hizmeti zorunluluk haline gelmiştir (İRO, 2017). 
Türkiye'de rehberliğin gerektirdiği çağdaş yasal düzenlemeleri içeren bir yasa önerisi “6326 Sayılı Turist Rehberliği Meslek Kanunu” 07.06.2012 tarihinde TBMM'de kabul edilmiş, 22.06.2012 tarihli Resmi Gazete 'de yayımlanmıştır (TUREB, 2013). 23 Şubat 2013 tarihli resmi gazetede yayınlanan Turist Rehberliği Meslek Yönetmeliği’nde bazı değişikliklere gidilmiştir. Yönetmelikte yapılan değişikliklerden biri ise (madde 3) aktif ve pasif rehberlik kavramı yerine "eylemli" ve "eylemsiz" kavramlarının getirilmesi olmuştur (Eker vd., 2017: 144).

\section{Kaçak Rehberlik Faaliyeti}

6326 sayılı Turist Rehberliği Meslek Kanununa göre herhangi bir rehberlik odasına üyeliği olmaması ve/veya bir turist rehberi olmak için gereken özellikleri taşımamasına rağmen bir acente ya da bağımsız olarak oluşturduğu tur vasıtasıyla rehberlik faaliyeti yapan kişiler "kaçak rehber" olarak ifade edilmektedir (Çakmak, 2019: 32).

Profesyonel turist rehberlerinin mesleklerinin icra etmelerinde kaçak rehberlik faaliyeti büyük sorun teşkil etmektedir. $\mathrm{Bu}$ bağlamda rehberlik alanında yapılan çalışmalar içerisinde de fazlaca incelenmektedir. Chowdhary ve Prakash (2008), turist rehberliğinin zorluklarını Hindistan örneği üzerinde incelemişlerdir. Çalışmada, Hindistan'daki turistlerin karşılaştığı sorunların çoğunun eğitimsiz ve kaçak rehberlerden kaynaklandığını ortaya koymuşlardır.

Güzel ve arkadaşları (2014), profesyonel turist rehberlerinin mesleki engellerini belirlemeye yönelik yaptıkları çalışmadan elde ettikleri bulgular ile katılımcıların mesleklerini gerçekleştirmeleri karşısında engel olarak gördükleri en önemli problemin kaçak rehberlik olduğu sonucuna ulaşmışlardır. Yenipınar ve arkadaşları (2017) turizmin yoğun olduğu dönemlerde, turistik destinasyonlarda yeni acentelerin varlığının artması ve kaçak rehberler ile çalışmaları durumunun turist rehberlerine büyük bir sorun oluşturduğunu ifade etmişlerdir. Eker ve Zengin (2017) turist rehberliği meslek kanunun profesyonel turist rehberleri tarafından değerlendirilmesi üzerine yaptıkları çalışmalarında mesleğin kanun ile yasal bir statüye ulaştığını ancak kaçak rehberlik sorununa çözüm getirmede yetersiz olduğu ve rehberlerin kaçak rehberlik sorunu ile çok sık karşılaştıklarını belirtmişlerdir.

Karacaoğlu ve Sert (2018), Kapadokya örneği üzerinden turist rehberlerinin mesleki sorunları üzerine yaptıkları çalışmada katılımcıların tamamının mesleklerini gerçekleştirmede önlerinde en önemli engelin kaçak rehberlik faaliyetleri olduğunu vurgulamışlardır. Saatçi ve Demirbulat (2018), 2017 y1lı Turist Rehberleri Birliği Denetim raporlarını incelemiş ve denetimlerin yetersizliği ile kaçak rehberlik faaliyetlerinin günümüzde büyük bir sorun olarak varlığını devam ettirdiğini ifade etmişlerdir. Brito (2020), turist rehberlerinin statüsü ve eğitimi için rehberlik mesleğinin serbest bırakılmasının 
sonuçlarını Portekiz ülkesine genel bir bakış açısı ile incelemiştir. Çalışma sonucunda lisansh rehberlerin lisanssız rehberlere göre daha tematik turlar düzenledikleri, lisanssız rehberlerin yol gösterici teknikler hakkında bilgi sahibi olmadığı̆, lisanslı rehber ile çalışmanın kalite anlamına geldiği ve ticaret imajını geliştirdiğine ulaşmıştır.

\section{YÖNTEM}

Çalışmada profesyonel turist rehberlerinin kaçak rehberlik faaliyetlerine karşı düşüncelerinin tespit edilmesi ve kaçak rehberlik faaliyetlerinin önlenmesine ilişkin çözüm önerilerinin geliştirilmesi amaçlanmaktadır. Gerçekleştirilen bu çalışmada, açıklayıcı araştırma modelinden yararlanılmıştır. Açıklayıcı araştırma modeli, araştırmacıların karşılaştıkları sorun durumlarını tanımlamaya yardımcı olan ya da tüketici motivasyonları, algılamaları, tutumları ve davranışlarının daha iyi anlaşılmasına yardımcı olan bir araştırma modelidir (Hair vd., 2017: 36).

Çalışmada, nitel araştırma yöntemlerinden biri olan yarı yapılandırılmış görüşme tekniği kullanılarak profesyonel turist rehberlerinden veriler elde edilmiştir. Yarı yapılandırılmış görüşme tekniği, nitel uygulamalı araştırmalarda en yaygın kullanılan veri toplama yöntemlerinden biri olarak tanımlanmaktadır (King, 2004: 11). Araştırmacıların ele aldığg konuya ilişkin katılımcılara yönelttiği bir takım açık uçlu soruların sorulduğu bu teknikle yanıtlayıcılardan alınan cevaplar karşılığında başka yeni soruların da sorulmasına imkân tanınmaktadır (Mathers vd., 2002: 2). Yarı yapılandırılmış görüşme tekniğinde öğrenilmek istenilen konu katılımcılara yöneltilir, verilen cevaplar doğrultusunda katılımcılara bağlı olarak elde edilen veriler farklılık gösterebilmektedir (Fylan, 2005: 65).

Araştırmanın evrenini “Turist Rehberleri Birliği” bünyesinde görev yapmakta olan profesyonel turist rehberleri oluşturmaktadır. Evren içerisinde yer alan profesyonel turist rehberlerinin hepsine ulaşılmasının güç olması nedeniyle yargısal örnekleme yönteminden yararlanılmıştır. Bu örnekleme yöntemi araştırmanın amacına uygun katılımcıların herhangi bir olasılığa dayanmadan seçilmesine imkân tanımaktadır (Kavak, 2017: 225). Örneklem grubu içerisinde yer alan katılımcılar araştırma içerisindeki sorulara en uygun cevabı verebilecek kişilerden seçilmektedir (Coşkun vd., 2017: 149).

Nitel araştırma yöntemi ile gerçekleştirilen çalışmalarda seçilen örneklemin büyüklügünün 15 ve üzeri olması yeterli olarak görülmektedir (Mason, 2010). Bu örnekleme yönteminden hareketle, araştırma kapsamında 23 profesyonel turist rehberine e-posta yolu ile ulaşılmıştır. Rehberler ile paylaşılan görüşme formundan elde edilen veriler MAXQDA.20 analiz programında düzenlenerek içerik analizine tabi tutulmuştur. İçerik analizi, yazılı ve görsel verilerin analizinde sıklıkla kullanılan nitel yöntemlerden biridir (Silverman, 2001: 60). Görüşme formunda yer alan sorular ilgili literatür 
taraması sonucu elde edilen bilgiler ve uzman görüşü alınarak çalışmaya eklenmiştir. Yapılan görüşmelerde aşağıdaki araştırma sorularına cevap aranmıştır:

1) Mesleki deneyiminiz hakkında bilgi verir misiniz?

2) Profesyonel turist rehberliğinin olumlu ve olumsuz özellikleri nelerdir?

3) Mesleği icra ettiğiniz bölgedeki kaçak rehberlik faaliyetlerinin yoğunluğu ile ilgili bilgi verebilir misiniz?

4) Kaçak rehberlik faaliyetlerine şahit olduğunuzda ne gibi tepkiler verirsiniz?

5) Kaçak rehberlik faaliyetlerinin turist rehberliği mesleğine ne gibi etkileri vardır?

6) Kaçak rehberlik faaliyetlerini önlemek adına paydaşlara düşen görevler nelerdir?

\section{BULGULAR}

Araştırmadan elde edilen veriler doğrultusunda katılımcıların demografik özelliklerine yönelik bulguları gösteren tablo aşağıda verilmiştir.

Tablo 1. Demografik Veriler

\begin{tabular}{|l|c|c|}
\hline Değişkenler & Sıklık (n) & Yüzde Değeri (\%) \\
\hline Cinsiyet & 4 & 17,39 \\
Kadın & 19 & 82,61 \\
Erkek & 3 & \\
\hline Mesleki Tecrübe & 13,04 \\
Bir y1ldan az & 14 & 60,87 \\
$1-3$ y1l aras1 & 2 & 8,70 \\
$4-6$ y1l aras1 & 3 & 13,04 \\
7-9 y1l aras1 & 1 & 4,35 \\
10 ve üzeri & & \\
\hline
\end{tabular}

Demografik özelliklerine ilişkin sonuçlar; katılımcılardan 19'u erkek, 4 tanesi ise kadındır. “Kaç yıldır profesyonel rehberlik mesleğini icra ediyorsunuz?" sorusuna ise; bir yıldan az (3), 1-3 y1l arası (14), 4-6 yıl arası (2), 7-9 yıl arası (3), 10 yıl ve üzeri (1) olarak tespit edilmiştir.

Tablo 2. Rehberlerin Çalışma Bölgeleri/ Çalışma Kartlarında Yazılı Olan Dil/ler

\begin{tabular}{|l|c|c|l|c|c|}
\hline \multicolumn{1}{|c|}{ Değişkenler } & $\begin{array}{c}\text { Sıklık } \\
\text { (n) }\end{array}$ & $\begin{array}{c}\text { Yüzde Değeri } \\
(\mathbf{\%})\end{array}$ & \multicolumn{1}{|c|}{ Değişkenler } & $\begin{array}{c}\text { Sıklık } \\
\text { (n) }\end{array}$ & $\begin{array}{c}\text { Yüzde Değeri } \\
\text { (\%) }\end{array}$ \\
\hline Çalışma Bölgeleri & & & Çalışma Kartında & & \\
İç Anadolu & 17 & 42,50 & Yazllı Dil/ler & & \\
Marmara & 7 & 17,50 & İngilizce & 23 & 95,83 \\
Karadeniz & 5 & 12,50 & Almanca & 1 & 4,17 \\
Ege & 3 & 7,50 & & & \\
Akdeniz & 3 & 7,50 & & & \\
Doğu Anadolu & 2 & 5,00 & & & \\
Belirtilmemiş & 3 & 7,50 & & & \\
\hline
\end{tabular}


Katılımcılara çalışma kartlarında yazılan dil veya diller sorulmuştur. Turist rehberliği meslek yönetmeliğine göre mesleği gerçekleştiren rehberlerin en az bir dili iyi seviyede bilmeleri gerekmektedir. Rehberlerin çalışma kartlarında yazılı olan dil birden fazlada olabilmektedir (Sert \& Karacaoğlu, 2018: 87). Çalışmada yer alan 23 katılımcının çalışma kartlarında İngilizce dilinde hizmet verdiği belirlenmiştir. İkinci bir dil olarak ise 1 katılımcının Almanca dilinde hizmet verdiği tespit edilmiştir.

Katılımcılara çalışma bölgeleri ve kaç yıldır bu mesleği icra ettikleri sorulmuştur. Bu soruya katılımcılar birden fazla bölgede turist rehberliği yaptıklarını ifade etmiştir. Yanıtlara bakıldığında; İç Anadolu bölgesi (17), Marmara bölgesi (7), Karadeniz bölgesi (5), Ege bölgesi (3), Akdeniz bölgesi (3) ve son olarak Doğu Anadolu bölgesi (2) cevapları elde edilmiştir. Katılımcılardan 3 tanesi ise çalışma bölgelerini belirtmemiştir.

Strauss ve Corbin (1990) üç tür kodlama biçiminden söz etmektedir. Çalışma içerisinde kullanılan kodların isimlendirilmesinde literatürde bulunan bu üç türden biri olan "verilerden çıkarılan kavramlara göre kodlama" kullanılmıştır. Bu tür kodlama, kavramsal yapıların olmadığı durumlarda tümevarımcı bir bakış açısı ile araştırmacı tarafından ortaya çıkarılır (Yıldırım ve Şimşek, 2011: 233).

Görüşme sorularından elde edilen veriler analiz edilerek en fazla değinilen konular belirlenmiştir. Toplanan metinler içinde geçen kelimelerin sıklığından (denetim, cezai işlem, turisti bilgilendirme) üç kod, yanıtlayıcıların bahsettiği konuların benzer içerik çağrışımlarından (yoğunluk, sahip çıkma, mesleki imaj, destinasyon imajı, sessizlik, acente firsatçılığı) altı kod oluşturulmuştur.

Görüşme sorularına verilen cevapların içerik analizinde iki kodlayıcı kullanılmıştır. Kodlayıcıların gerçekleştirdikleri kodlar karşılaştırılarak, fikir birliğine varılamayan maddeler üzerinde gerekli düzenlemeler yapılmıştır.

Tablo 3. Kod Listesi

\begin{tabular}{|c|c|c|c|}
\hline Sorular & Kodlar & $\begin{array}{l}\text { Sıklık } \\
\text { (n) }\end{array}$ & $\begin{array}{l}\text { Yüzde Değeri } \\
(\%)\end{array}$ \\
\hline $\begin{array}{l}\text { Mesleği icra ettiğiniz bölgedeki kaçak rehberlik } \\
\text { faaliyetlerinin yoğunluğu ile ilgili bilgi verebilir } \\
\text { misiniz? }\end{array}$ & Yoğunluk & 18 & 78,3 \\
\hline \multirow{2}{*}{$\begin{array}{l}\text { Kaçak rehberlik faaliyetine şahit olduğunuzda ne } \\
\text { gibi tepkiler verirsiniz? }\end{array}$} & Sahip Ç1kma & 22 & 95,7 \\
\hline & Sessizlik & 5 & 21,7 \\
\hline \multirow{2}{*}{$\begin{array}{l}\text { Kaçak rehberlik faaliyetlerinin turist rehberliği } \\
\text { mesleğine ne gibi etkileri vardır? }\end{array}$} & Mesleki İmaj & 17 & 73,9 \\
\hline & Destinasyon İmaj1 & 11 & 42,8 \\
\hline \multirow{4}{*}{$\begin{array}{l}\text { Kaçak rehberlik faaliyetlerini önlemek adına } \\
\text { paydaşlara düşen görevler nelerdir? }\end{array}$} & Denetim & 17 & 73,9 \\
\hline & Acente Firsatçılığ & 15 & 65,2 \\
\hline & Cezai İşlem & 12 & 52,2 \\
\hline & Turisti Bilgilendirme & 12 & 52,2 \\
\hline
\end{tabular}


Tablo 3'de yer alan bulgular doğrultusunda, "Mesleği icra ettiğiniz bölgedeki kaçak rehberlik faaliyetlerinin yoğunluğu ile ilgili bilgi verir misiniz?” sorusu katılımcılar çalıştıkları bölgede sık sık kaçak rehberlik faaliyetleri ile karşılaştıklarını dile getirmişlerdir. Rehberler yaşanan bu olumsuz durum için; kaçak rehberler olduğu sürece profesyonel rehberlik yapan kişilerin işlerinden olduğunu maddi ve manevi olarak etkilendiklerini ifade etmişlerdir:

“Açıkçası Eskişehir ve Ankara'yı kaçak rehberlik faaliyetlerinin ana bölgesi olarak görmek mümkün. Özellikle klş sezonlarında bazı meslektaşlarımız evinde otururken bu kaçak rehberlerle turlarda karşılaşmak mümkün ve oldukça can sıkıcı bir durum." (K2, Erkek).

“Ben çalıştığım dönemde haftada 6 gün tura çıkıyordum. İstanbul'da karşılaştığım kaçak rehberlik faaliyetleri oldu tabi ki hatta neredeyse her hafta karşıma bir kaçak rehber çıkıyordu maalesef." (K4, Erkek).

“Balıkesir'in Ayvalık Bölgesine düzenlenen turlarda Profesyonel Turist Rehberi görebilmek için şanslı olmak zorundasınız." (K7, Erkek).

Katılımcıların neredeyse tamamı rehberlik meslekleri boyunca kaçak rehberlik faaliyetleri ile karşılaştıklarını yaşanan bu durumun motivasyonlarını etkilediğini ve işsiz kalmalarına sebep olduğuna değinmişlerdir. Katılımcılardan elde edilen veriler MAXQDA.20 programı ile düzenlenmiş ardından benzer yanıtlar "yoğunluk" kodu altında toplanmıştır. 78,3'lük bir değer ile yoğunluk kodu için kaçak rehberlik faaliyetlerinin fazla olduğuna dair yorum yapılabilir.

“Kaçak rehberlik faaliyetine şahit olduğunuzda ne gibi tepkiler verirsiniz?” sorusuna katılımcıların çoğunluğu o an yapılabilecek faaliyet olarak kaçak rehberlik yapan kişinin fotoğrafını çekerek ya da araç plakasını alarak ilgili mercilere gönderebileceklerini ifade etmişlerdir. Fotoğraflama haricinde TUREB'i bilgilendireceklerini ayrıca kendi rehberlik gruplarından diğer rehber arkadaşlarını bu durumdan haberdar edeceklerini dile getirmişlerdir. Bunun dışında o an kaçak rehberlik yapılan turun huzurunu kaçırmamak adına sessiz kaldıklarını, kendi turlarında ki misafirlere yalnızca bilgilendirme yaptıklarını ifade etmişlerdir.

Kaçak rehberlik faaliyeti profesyonel turist rehberlerinin mesleki sorunlarının başında gelmektedir (Sert, Karacaoğlu, 2018: 92). Günümüzde hala devamlılığını sürdüren ve önüne geçilemeyen kaçak rehberlik faaliyeti profesyonel turist rehberlerinin de mesleklerini olumsuz etkilediği görülmektedir. Yaşanan bu durum karşısında profesyonel turist rehberleri mesleklerine sahip çıkmak adına birlik ve beraberlik sağlayarak kaçak rehberlik faaliyetlerinin önüne geçilebileceğini ifade etmektedirler: 
"Şahısların fotoğraflarını çekip haklarında edinebildiğim kadar bilgi edinmeye çalışırım. Bunun bir suç olduğunu farkında olmalarına rağmen yaptıklarını iletirim birlikten kuvvet doğar bu yüzden rehber platformlarında paylaşımı ile şirket ve şahsın bilgilerini paylaşırım takiben de TÜRSAB ve TUREB'e şikâyet iletilir." (K8, Erkek).

"Böyle bir duruma sahip olduğumda öncelikle meslektaşlarım ile iletişime geçerek bu durumun farkında olmalarını sağllyorum. Daha sonra meslektaşlarımın da bulunduğu sosyal ağlarda (Whatsapp vb) faaliyeti yapan kişinin fotoğrafinı paylaşıyorum. Zaten bu ăglardaki deneyimli ve kaçak rehberlik ile ilgili denetimlerde daha önce bulunmuş veya bu denetimleri sağlayacak kişilere ulaşabilen meslektaşlarım sayesinde bu faaliyetin denetlenmesinde aracı oluyorum.” (K16, Erkek).

"Rehber meslektaşlarımız da kaçak rehberlik faaliyetleri ile karşılaştığında mutlaka tepki göstermelidir." (K14, Kadın).

Katılımcıların cevaplarına bakıldığında birçoğu benzer yanıtları vermiştir. Kaçak rehberlik faaliyetinin önüne geçilmesi için profesyonel turist rehberleri mesleklerine sahip çıkmaları gerektiklerini. Bununla birlikte rehberler arası örgüt ve dayanışma ile azaltılabileceğini değinmişlerdir. Katılımcılardan elde edilen veriler "sahip çıkma" kodu ile bir başlık altında toplanmıştır.

Profesyonel turist rehberlerinin mesleki sorunların biri olan kaçak rehberlik faaliyetleri ile karşılaşma sonrası verdikleri tepkiler "Sahip çıkma" ile en yüksek değere sahip olan kod 22 cümle içerisinde \%95,7’lik bir değer ile oldukça fazla vurgulanmıştır.

Katılımcılar “kaçak rehberlik faaliyetleri ile karşılaştığınızda ne gibi tepkiler verirsiniz?” sorusuna her ne kadar mesleklerine sahip çıkmaları gerektiğini vurgulasalar da o an sessiz kalmaları gerektiğini belirten rehberler de bulunmaktadır. Rehberler kendi turlarının huzurunu kaçırmamak ve karşı turu rahatsız etmemek için müdahale etmediklerini ifade etmişlerdir:

“Tabi ki hiçbir tepki veremiyoruz çünkü tur sırasında gurubu bir kenara bırakıp kaçak rehberlikyapan kişilerle polemiğe girmek mümkün değil. Daha önce şahit olduğum bazı olaylar tepki vermenin pek işe yaradı̆̆ını düşünmeme neden oldu.” (K4, Erkek).

"Herhangi bir tepki vermenin benim sorumluluğumda olmadı $\breve{l}$ ortadadır. Bu faaliyetin muhatabı denetmenler ve kolluk kuvvetleridir." (K7, Erkek).

"Hiçbir tepki vermiyorum. Verdiğimde karşı tarafla sorun yaşamaktan çekiniyorum. Çünkü o anda bende bir gruba rehberlik yapıyor oluyorum. Hem benim grubunun hem de kaçak rehberin grubunun huzuru kaçsın istemiyorum. Çünkü karşı tarafın ne kadar hırsız olduğunu düşünsem de onun grubundaki insanların hiçbir suçu yok." (K12, Erkek). 
Görüşme sorularından toplanan verilere bakıldığında ne kadar az bir oran da olsa rehberlerin yaşadığı olumsuz durum karşısında belirttikleri sessiz kalma düşüncesi “sessizlik” kodu altında yer verilmiştir. Toplamda benzer 5 cümle “sessizlik” kodu altında 21,7'lik bir orana sahiptir.

Katılımcılara beşinci soru olan, "Kaçak rehberlik faaliyetlerinin turist rehberliği mesleğine ne gibi etkileri vardır?” sorusuna rehberlerin çoğunluğu yanlış kişiler tarafından, yanlış şekilde temsil edilmesi sebebi ile mesleklerinin itibarını kaybettiğini, insanların gözünde mesleki imajlarının zedelendiğini dile getirmişlerdir. Bunun dışında kaçak rehberlik yapan kişilerin taban ücretinin altında çalışmaları profesyonel turistlerinin tura çıkamamalarına sebebiyet vermektedir. Katılımcılar görüşme sorularına verilen yanıtlarda, haksız kazanç elde ettiklerini ve maddi anlamda kayıp yaşadıklarını ifade etmişlerdir:

“Ayrıca yasalarla belirlenen ücretlerimiz mevcut kaçak rehberlik yapanların ne kadar ucuz fiyatlara çıktığını biliyoruz. Özellikle boş sezonlarda rehberlerimiz evlerinde yatarken bu insanlar 100 TL, 200 TL gibi komik rakamlara turlara çıkmakta ve bizim işimize engel olmakta.” (K2, Erkek).

“Turist rehberliği mesleğinin güvenilirliği, küçük etkiler ile çok kolay bir şekilde sarsılabilmektedir. Kelebek etkisi örneği gibi bir bireyin gerçekleştirdi olumsuz bir etki insanların genel olarak tüm turist rehberlerine bakış açısını olumsuz etkileyebilmektedir. Bu da dolayısıyla turist rehberine olan talebi düsürmekte ve mesleğin sürekliliğini tehlikeye atmaktadır." (K18, Erkek).

Katılımcılar kaçak rehberlik faaliyetlerinin diğer bir olumsuz etkisi olarak destinasyonun yanlış kişiler tarafından doğru olmayan bilgiler ile tanıtılması sonucu hem kamunun hem yerel kültürün hem de rehberlerin etkilendiğini dile getirmişlerdir. Gerçek anlamda destinasyonların tanıtılmadığını sadece kazanç odaklı olarak bilgiden ziyade alışverişin ön planda tutulduğuna değinilmiştir.

“En başta rehberlik faaliyetinin niteliğini olumsuz yönde etkilemektedir. Rehberlik mesleği gerek yerli gerek yabancı turistlerin gezdikleri turistik bölgeyi algılamalarını, memnuniyetlerini, tekrar ziyaret etmeleri ciddi oranda etkilemektedir. Bu nedenle kaçak rehberlik faaliyetine katılan bu turistler kötü deneyim sahibi olabilmekte ve destinasyona karşı olumsuz düşüncelere sahip olabilmektedir. Turistlerin gezdikleri yerlerden memnun olmadan ayrllmalarını ve ă̆ıdan ă̆ıza pazarlama yoluyla çevresindeki potansiyel turistlerin de gezilen yere gitmemesine yol açabilmektedir.” (K16, Erkek).

"Her şeyden önce o kişi, sizin kazanabileceğiniz bir parayl, hem yasal hem de etik olarak hak etmediği halde kendisi almaktadır. Kaldı ki yaptı̆̆ şey yasal değildir. Çok sayıda lisanslı rehber evinde iş beklerken, bu kişi ya da kişilerin sizin hakkınızı gasp ettiği açıktır. İşin maddi boyutu bir yana, bu kişiler yalan yanlış bilgilerle gruplara ülke/bölge hakkında doğru olmayan sunumlar yapmaktadirlar." (K23, Erkek). 
Katılımcıların, kaçak rehberlik faaliyetlerinden mesleki açıdan olumsuz etkilerini, yanlış tanıtım, maddi kayıp, mesleki itibarsızlık, haksız kazanç olarak belirtmişlerdir. Elde edilen mesleki etki verileri ikiye ayırılarak "mesleki imaj" ve "destinasyon imajı" kodları altında toplanmıştır. "Mesleki imaj” kodu benzer içerikler ile 17 cümle içerisinde 73,9'lük bir değere sahipken diğer bir kod olan “Destinasyon imajı” ise 11 benzer cümle içerisinde geçerek 42,8’lik bir değere sahip olmuştur.

“Kaçak rehberlik faaliyetlerini önlemek adına paydaşlara düşen görevler nelerdir?” sorusuna katılımcılar sırayla; denetimlerin arttırılması (17), kaçak rehberlik faaliyetlerine sırf ucuz işgücü olduğu için müsaade eden acentelerin bilinçlenmesi (15), caydırıcı cezaların uygulanması (12) ve son olarak turistlerin bu konu hakkında bilgilendirilmesi (12) olarak önerilerde bulunulmuştur.

Katılımcılar denetimlerin yeterli derecede olmadığını bu sebeple kaçak rehberlerin rahat bir şekilde tur yaptıklarını, acentelerin uygun fiyatlı kaçak rehber çalıştırdıkları için profesyonel turist rehberlerinin iş bulamadığını, cezaların kaçak rehberlik faaliyetlerinden vazgeçirecek kadar caydırıcı olmadığını bununla birlikte cezaların uygulanmadığını belirtmişlerdir. Katılımcılar tura katılan turistlerin ise bu konuda bilinçlenerek tur rehberlerine kokartlarını göstermelerini istemelerini dile getirmişlerdir. Kaçak rehberli bir turda iseler acentelerden ücretlerini iade etmeleri noktasında öneride bulunmuşlardır. Rehberler en büyük önlemin kolluk kuvvetlerinde olduğunu ifade etmişlerdir:

“Denetimlerin arttırlmasl gerektiğini düşünüyorum. Yoğun sezonlarda denetim eksikliğinden bu insanlar gözümüzün içine baka baka tur yapabiliyorlar ve bu konuda rehberlere yetki verilmesi gerektiğini düşünüyorum." (K2, Erkek).

“TUREB 'in bu konuda özellikle denetimleri korkulacak derecede yüksek tutması gerek bahsettiğim bu konulara dikkat edilmesi halinde kaçak rehber çıkaracak acente bulunamaz.” (K4, Erkek).

"Kaçak rehberlik faaliyetlerini önlemenin tek yolu sıkı denetim yapmak. Bu konuda sorumluluk TUREB, TÜRSAB ve odalarin." (K6, Erkek).

"Dışarıdan bakınca ne yazık ki bazı acenteler ve insanlar Eskişehir de ne var rehberlik deyip daha ucuz olduğu için kacak rehber tercih ediyorlar." (K19, Erkek).

“Özellikle belli turizm merkezlerinde, acenteler maliyet düşürmek için kaçak rehber çalıştırlyorlar, denetimlere rağmen." (K23, Erkek).

"Denetimler sıklaştırılıp cezaların caydırıcılı̆̆ artırılmalıdır. Bunun için ise bürokratik zorluklar ortadan kaldırllmalı. Bir kaçak rehber denetleme olacağını 10 gün öncesinden biliyor. Denetimin hızlı bir kararla hayata geçirilip gerçekleştirilmesi gerekli." (K12, Erkek). 
“Turistler kültür turlarında mutlaka çalışma kartlı profesyonel turist rehberi olduğunu teyit etmeli. Rehberler her daim birlik ve beraberliklerini korumall. Resmi sayfalarda, toplumsal alanlarda ve turistik noktalarda reklam panoları $v b$. Unsurları kültür turlarında profesyonel turist rehberi önemi vurgulanabilir. Olmamasının suç olduğu ve şikâyet hattı oluşturup turistlerin bilgisine sunula bilinir." (K8, Erkek).

Katılımcıların sık sık dile getirdikleri, denetimlerin arttırılması "denetim" kodu altında, acentelerin müsaade etmesi "acente fırsatçılığı” kodu altında, caydırıcı cezaların uygulanması gerektiği "cezai işlem" kodu altında ve son olarak turistlerin bilgilendirilmesi gerektiği "turisti bilgilendirme" kodu altında benzer yanıtlar toplanmıştır. Toplanan bu dört kodun frekansları alındığında, "denetim” kodu 17 benzer cümle içerisinde geçerek 73,9'luk bir değer ile en çok değinilen unsur olmuştur. "Acente Fırsatç1lı̆̆ı" kodu 15 benzer cümle ile 65,2'lik bir değer iken "cezai işlem" ve "turisti bilgilendirme" kodu 12 benzer cümle içerisinde geçerek 52,2’lik bir değere sahip olmuştur.

\section{SONUÇ ve ÖNERILER}

Turizm endüstrisinde önemli bir konuma sahip olan turist rehberleri mesleklerini icra ederken birçok sorunla karşılaşmaktadır. İncelenen çalışmalar doğrultusunda turist rehberlerinin karşılaştıkları mevcut sorunlar içerisinde kaçak rehberlik faaliyetinin de büyük bir sorun olarak işlendiği gözlemlenmiştir. Bu çalışmada "Turist Rehberliği Birliği” bünyesinde görev yapmakta olan profesyonel turist rehberlerinin kaçak rehberlik faaliyetlerine karşı düşüncelerinin belirlenmesi ve bu sorunun önlenmesine yönelik çözüm önerilerinin geliştirilmesi amaçlanmaktadır.

Araştırma kapsamında gerçekleştirilen içerik analizi sonucunda elde edilen bulgular, profesyonel turist rehberlerinin kaçak rehberlik faaliyetlerini önemli bir sorun olarak algıladıklarını göstermektedir. Elde edilen sonuçlara göre, yarıdan fazlası erkek olan profesyonel turist rehberine kaçak rehberlik faaliyetleri konusunda yarı yapılandırılmış görüşme soruları iletilmiştir. Bulgulara göre; kaçak rehberlik faaliyetinin yoğun olarak varlığının profesyonel turist rehberleri üzerinde maliyet kaygısı oluşturduğu ve bunun yanında manevi olarak etkilediği sonucuna ulaş1labilmektedir. Benzer şekilde, Yenipınar ve arkadaşları (2017), turist rehberliği mesleği ile ilgili güncel sorunların tespiti ile birlikte belirlen sorunlara önerileri geliştirilmesini amaçlayan bir çalışma yapmışlardır. Çalışmada, turist rehberlerinin, genellikle kriz gibi dış faktörlerin etkisi ile acentelerin maliyetini düşürmek için kaçak eleman çalıştırdıkları, taban ücretin altında ödeme teklifi vb. nitelikli işlerin azalması sonucunda işsizlik-geçim sıkıntısı yaşadıkları bulgulanmıştır.

Turistler, profesyonel turist rehberleri sayesinde ziyaret edilen destinasyonu doğru olarak tanımakta ve iyi bir tur deneyimi yaşamaktadırlar. Ancak geçmişten beri var olan kaçak rehberlik sorunundan 
dolayı ziyaret edilen destinasyonun yanlış tanıtıldı̆̆ 1 ve turistlerin kötü bir tur deneyimi yaşayarak turist rehberlerine karşı önyargılı oldukları anlaşılmaktadır. Bu bağlamda kaçak rehberlik faaliyetinin meslek imajını ve destinasyon imajını olumsuz yönde etkilediği görülmektedir. Bu bakış açısıyla, hangi tür rehberlik hizmetinde kaçak rehberlik faaliyetinin daha çok görüldüğünün tespit edilmesi önem taşımaktadır. Bununla ilgili olarak Çakmak (2019), yasa dışı rehberlik faaliyetlerinin kimler tarafından, hangi ülke grupları merkezli gerçekleştirildiğinin tespit edilerek bu turlarda hangi tür rehberlik hizmetinin talep edildiği ve nerelerde yoğunlaştığının belirlenmesini amaçlayan bir çalışma yürütmüştür. Çalışmadan elde edilen sonuçlar; kaçak rehberliğin, yasa dışı rehberlik faaliyetlerinin büyük çoğunluğunu oluşturduğu, kaçak rehber kullanımının olduğu turlarda yabancı grupların ağırlıklı olarak günübirlik turlarda, yerli grupların ise paket turlarda kaçak rehber kullanma eğiliminin yüksek olduğu şeklindedir.

Çalışmanın bir diğer önemli çıktısı, seyahat acentelerinin maliyetlerini azaltmak adı altında kaçak rehberleri çalıştırdıkları ve bu durumun yasal olarak mesleğin icra edilmesinin önündeki önemli bir engel olarak yer aldığı gözlenmektedir. Kaçak rehberlik faaliyeti ile karşı karşıya kalan turist rehberlerinin kendi tur içerisindeki huzurunu bozmamak ve yapacağı müdahalenin işe yaramayacağını düşünerek sessiz kaldığı görülmektedir. Yoğun olarak kaçak rehberlik faaliyeti ile karşılaşılmasının önündeki temel nedenlerin de denetimlerin ve cezai işlemlerin yetersiz kalmasından dolayı olduğu tespit edilmektedir. Ayrıca turistlerin yeteri kadar bilinçli olmadığı sonucuna ulaşılabilmektedir. Karacaoğlu ve Sert (2018) de çalışmalarında, kaçak rehberlik faaliyetleri ve seyahat acentelerinin taban ücretin altında turist rehberi çalıştırmak istemelerinin birbirleriyle bağlantılı konular olduğunu ifade etmişlerdir.

Çalışma sonuçlarına dayanarak, katılımcıların görüşleri doğrultusunda birtakım öneriler geliştirilmiştir. Kaçak olarak gerçekleştirilen rehberlik faaliyetleri için yasada yer alan cezaların arttırılması, denetimlerin sıklaştırılması ve cezai işlemlerin caydırıcı şekilde düzenlenmesi gerekmektedir. $\mathrm{Bu}$ düzenlemeler kaçak rehberlik faaliyetini yapan rehber ve buna müsaade eden seyahat acentesine eş zamanlı uygulanmalıdır. TUREB, TÜRSAB gibi kuruluşlar iş birliği yapmalı ve bu konu kapsamında daha çözüm odaklı farklı öneriler getirmelidirler. Şehirlerde reklam panolarına, şehir tanıtım broşürlerine profesyonel turist rehberliği mesleğinin yasal olarak gerçekleştirilmesi gerektiğini ve bir turda rehberin kaçak olup olmadığının nasıl anlaşılması gerektiğini anlatan görsel ve yazılı sunumlar hazırlanabilir.

Kaçak rehberlik faaliyeti sorunun çözüme kavuşması için rehberlerin birbirleriyle iletişim halinde olmaları ve mesleklerine sahip çıkmaları gerekmektedir. Bu düşünceden yola çıkarak gelişen teknoloji imkânları göz önüne alındığında her şehir için bir iletişim platformu kurularak (örn: web sitesi ya da 
mobil uygulamalar) o şehirde rehberlik yapan kişilerin bilgileri, düzenlenen turlar hakkında bilgilerin bulunması ve sürekli iletişim gerçekleştirdikleri bu platform sayesinde kaçak rehberlik faaliyetlerinin önüne geçilmesi hedeflenebilir.

$\mathrm{Bu}$ çalışmanın birtakım kısıtları bulunmaktadır. Bunlardan ilki çalışmanın Covid-19 pandemi sürecinden dolayı yüz yüze gerçekleştirilemeyip, katılımcılara yalnızca e-mail yolu ile ulaşılmasıdır. Diğer kısıtlama ise çalışmanın verilerinin belirli bir zaman diliminde elde edilmesinden dolayı kısıtlı sayıda rehber ile iletişime geçilmesidir. Gelecek araştırmalar için, Türkiye genelinde, örneklem sayısı daha fazla, farklı veri toplama tekniklerini kapsayan çalışmalar önerilebilir. Bu kapsamda Türkiye'deki günlük ve paket turların en sık yapıldığı destinasyonlar seçilebilir. Bunun yanı sıra profesyonel turist rehberleri yerine kaçak rehberler ile görüşülüp mevcut soruna farklı bir bakış açısı ile bakılabilir. 


\section{KAYNAKÇA}

Ahipaşaoğlu, S. (2006). Turizmde Rehberlik. Ankara: Detay Yayıncılık.

Ap, J., Wong, K. K.F. (2001). Case Study on Tour Guiding: Professionalism, Issues and Problems. Journal of Tourism Management, (22), 551-563.

Avcıkurt, C. (2009). Turizm Sosyolojisi: Genel ve Yapısal Yaklaşım. Ankara: Detay Yayınc1lik.

Brito, L. M. (2020). The Consequences of Guiding Profession Deregulation for the Status and Training of Tourist Guides: a Portuguese Overview. International Journal of Tour Guiding Research, 1(1), 34-44.

Camilleri, M. (2017). The Tourism Industry: An Overview. In Travel Marketing, Tourism Economics and the Airline Product (Chapter 1, pp. 3-27). Cham, Switzerland: Springer Nature.

Chowdhary, N., Prakash, M. (2008). Challenges of Tourist Guiding-An Assessment of Situation in India. Part VII - Tourism Infrastructure, Technology \& Operations: 287-302.

Cohen, E. (1985). The Tourist Guide The Origins, Structure and Dynamics of a Role. Annals of Tourism Research, 12(1), 5-29.

Coskun, R. Altunışık, R., Yıldırım, E. (2017). Sosyal Bilimlerde Araştırma Yöntemleri SPSS Uygulamalı: İstanbul: Sakarya Yayıncılık.

Çakmak, T. F. (2019). Yasa Dışı Rehberlik Faaliyetlerinin İçerik Analizi Yoluyla İncelenmesi: İstanbul Rehberler Odası Örneği. Turizm Akademik Dergisi, (2), 31 40.

Çokal, Z. (2019). Turist Rehberlerinin Performansının Destinasyon İmajına Etkisinde Etik Davranışlarının Düzenleyici Rolü: Nevşehir Örneği. (Yayımlanmamış Doktora Tezi). Nevşehir Hacı Bektaş Veli Üniversitesi/Sosyal Bilimler Enstitüsü, Nevşehir.

Dahles, H. (2002). The Politics of Tour Guiding Image Management in Indonesia. Annals of Tourism Research, 29(3), 783-800.

Eker, N., Zengin, B., Bayram, G. (2017). Turist Rehberliği Meslek Kanununun Profesyonel Turist Rehberlerince Değerlendirilmesi. Seyahat ve Otel İşletmeciliği Dergisi, 14(2), 142-156.

Fylan, F. (2005). A Handbook Od Research Methods Clinical \& Health Psychology. Jeremy, M. \& Paul, G. (Ed.) Semi-structured interviewing (Chapter 6, pp. 65-78). New York: Oxford University Press.

Genç, E. (2018). Turist Rehberlerinin Yaşadıkları Zorlukların Kariyer Bağlılığına Etkisi. (Yayımlanmamış Yüksek Lisans Tezi). Mersin Üniversitesi/Sosyal Bilimler Enstitüsü, Mersin. 
Güzel, Ö., Türker, A., Şahin, İ. (2014). Profesyonel Turist Rehberlerinin Algıladıkları Mesleki Engelleri Belirlemeye Yönelik Bir Araştırma. Gazi Üniversitesi Turizm Fakültesi Dergisi, (2), 173-190.

Hair, J. F., Celsi, M. Ortinau D. J., Bush, R. P. (2017). Essentials of Marketing Research. (4. Bask1). New York: McGraw-Hill Education.

İstanbul Rehberler Odas1 (İRO), (2017). Rehberliğin Tarihçesi. https://iro.org.tr/tr/53page-rehberligin-tarihcesi.aspx, Erişim Tarihi: 11.09.2020

Karacaoğlu, S., Sert, A. N. (2018). Turist Rehberlerinin Mesleki Sorunları Üzerine Bir Araştırma: Kapadokya Örneği. Journal of Tourism and Gastronomy Studies, 6(3), 81-99.

Kavak, B. (2017). Pazarlama ve Pazar Araştırmaları Tasarım ve Analiz. Ankara: Detay Yayincilik.

King, N. (2004). Essential Guide to Qualitative Methods in Organizational Research. Catherine, C. \& Gillian, S. (Ed.) Using interviews in qualitative research. London: SAGE Puplication.

Mason, M. (2010). Sample size and saturation in phd studies using qualitative interviews, Forum: Qualitative Social Research, 11(3), 1-19.

Mathers, N., Fox, N., Hunn, A. (1998). "Trend Focus for Research and Development in Primary Health Care Using Interviews in a Research Project."

Saatçi, G., Demirbulat, Ö. (2018). Turist Rehberleri Birliği'nin (TUREB) 2017 Y11 Denetim Raporlarının İncelenmesi. Turist Rehberliği Üzerine Güncel Araştırmalar (657-665), Ankara: Detay Yayınc1lık.

Silverman, D. (2001). Interpreting Qualitative Data: Methods for Analysing Talk, Text and Interaction. London: SAGE Publication.

Timur, A., Bardakoğlu, Ö. (2015). Turizm İşletmeciliği. Ankara: Detay Yayıncılık.

Toker, A. (2011). Kültür Turizminin Sürdürülebilirliğinde Profesyonel Turist Rehberlerinin Rolü: Ankara Örneği. (Yayımlanmamış Yüksek Lisans Tezi). Anadolu Üniversitesi/Sosyal Bilimler Enstitüsü, Eskişehir.

Turist Rehberleri Birliği (TUREB), (2013). Nas1l Rehber Olunur? http://www.tureb.org.tr/tr/Page/Detail/77, Erişim Tarihi: 11.09.2020

Turist Rehberleri Birliği (TUREB), (2019). Turist Rehberliği Meslek Kanunu. http://www.tureb.org.tr/tr/Page/Detail/60, Erişim Tarihi: 11.09.2020

World Federation of Tourist Guide Associations, (WFTGA), (2003). What is a tour guide? http://www.wftga.org/tourist-guiding/what-tourist-guide, Erişim Tarihi: 11.09.2020 
Yenipınar, U., Çınar, B., Bak, E. (2017). 3. Turizm Şurası 1-3 Kasım 2017 Tebliğler Kitabı. Turist Rehberliği Eğitimi ve Mesleğin Güncel Sorunları ve Çözüm Önerileri (306-320). Ankara: Özel Matbaası.

Yıldırım, A., Şimşek, H. (2011). Sosyal Bilimlerde Nitel Araştırma Yöntemleri. Ankara: Seçkin Yayıncılık. 